\title{
PERAN BRAND IMAGE DALAM MEMEDIASI PENGARUH HARGA TERHADAP NIAT PEMBELIAN (Studi Pada Produk Iphone Di Kota Denpasar)
}

\author{
AA Gd Agung Rahma Putra ${ }^{1}$ \\ Ni Made Asti Aksari ${ }^{2}$ \\ ${ }^{1,2}$ Fakultas Ekonomi dan Bisnis Universitas Udayana (Unud), Bali, Indonesia \\ e-mail: agungrahmaputra16@yahoo.com
}

\begin{abstract}
ABSTRAK
Dewasa ini persaingan semakin ketat, perusahaan dituntut untuk memahami perilaku konsumen dan menawarkan produk dengan harga yang terjangkau dan brand image yang baik. Tujuan dari penelitian ini adalah untuk mengetahui pengaruh harga terhadap brand image, pengaruh harga dan brand image terhadap niat pembelian, serta peran brand image dalam memediasi pengaruh harga terhadap niat pembelian pada produk iPhone di Denpasar. Populasi dalam penelitian ini adalah konsumen yang berniat untuk menggunakan produk iPhone. Metode penentuan sampel yang digunakan dalam studi ini adalah nonprobability sampling dengan teknik purposive sampling yaitu teknik penentuan sampel dengan pertimbangan tertentu. Sampel yang dipilih dalam penelitian ini sebanyak 110 responden. Data dianalisis menggunakan teknik analisis jalur. Hasil penelitian menunjukkan bahwa harga berpengaruh positif dan signifikan terhadap brand image iPhone, harga dan brand image berpengaruh positif dan signifikan terhadap niat pembelian konsumen pada produk iPhone, serta brand image mampu memediasi pengaruh harga terhadap niat pembelian produk iPhone di Denpasar.
\end{abstract}

Kata Kunci: harga, citra merek, niat pembelian

\begin{abstract}
The purpose of this study is to examine the effect of price on brand image, the effect of price and brand image on consumer purchase intention, and the role of brand image in mediating the effect of price on the purchase intention towards iPhone product in Denpasar City. The population of this study are consumers with the intention to use iPhone product. The sampling method used in this study is nonprobability sampling with purposive sampling technique by using certain consideration. The sample selected for this study was 110 respondents. Data is analysed using path analysis technique. The result of this research shows that price have a positive and significant effect on iPhone brand image, price and brand image have positive and significant effect on consumer purchase intention towards iPhone product, and brand image plays a mediating role on the relationship between price and purchase intention towards iPhone product in Denpasar.

Keywords: price, brand image, purchase intention
\end{abstract}




\section{PENDAHULUAN}

Dewasa ini persaingan dalam dunia bisnis semakin ketat, Ini yang membuat perusahaan dituntut untuk memahami perilaku konsumen dan menawarkan produk dengan harga yang terjangkau dan brand image yang baik agar memberikan minat yang tinggi bagi konsumen untuk memiliki produk yang ditawarkan (Triya, 2015). Sejalan dengan kemajuan dalam bidang ekonomi, maka pengembangan dunia usaha juga mengalami pertumbuhan dan kemajuan yang pesat. Semua ini dibuktikan dengan bermunculannya perusahaan-perusahaan baru. Semuanya berusaha memproduksi barang dan jasa untuk memenuhi kebutuhan dan keinginan konsumen yang semakin meningkat. Salah satu tujuan pendirian perusahaan adalah untuk mendapatkan keuntungan sebesar - besarnya, karena dengan keuntungan tersebut perusahaan dapat mengembangkan usahanya dan mempertahankan kelangsungan hidup perusahaan (He et al., 2013). Pencapaian laba perusahaan tersebut dilakukan melalui kegiatan penjualan hasil produksi. Tolak ukur hasil penjualan dapat dilihat dari jumlah produk atau jasa yang dapat dijual pada konsumen (Laksana, 2008:49). sehingga semakin besar jumlah produk yang dipasarkan atau dijual dapat dikatakan bahwa perusahaan tersebut berhasil didalam melaksanakan kegiatan penjualannya.

Di era globalisasi yang berkembang disegala bidang yang menuntut setiap orang untuk mempunyai pemikiran kreatif dan inovatif dalam menghadapi persaingan dibidang perekonomian, terutama dalam bidang telekomunikasi. Munculnya produk-produk komunikasi khususnya telepon genggam atau handphone merupakan solusi alat bantu komunikasi yang paling populer 
digunakan karena pemakaiannya yang mudah, efektif, dan efisien. Teknologi handphone selalu mengalami kemajuan dari waktu ke waktu. Pesatnya perkembangan teknologi digital yang ditandai dengan tingginya pengguna smartphone sebagai perangkat telekomunikasi, memunculkan peluang bisnis dalam bidang telekomunikasi, sehingga saat ini berbagai perusahaan berkompetisi menciptakan produk-produk yang terbaik dalam bidang telekomunikasi. Perkembangan yang pesat di dunia telekomunikasi ini tak luput dari peranan para pelaku industri telekomunikasi Indonesia (id.gopher.co.id).

Seiring dengan perkembangan waktu, smartphone mengalami banyak perubahan, misalnya pada penambahan fungsi atau kemampuan dari smartphone yang dulunya sebagian besar hanya digunakan untuk menerima telepon dan SMS (Short Messaging Service) berkembang menjadi Video Call. Kemudian saat ini dengan semakin majunya teknologi komunikasi membuat penambahan fitur-fitur baru yang mendukung kegunaan dari smartphone itu sendiri seperti misalnya beberapa aplikasi media sosial yaitu: Facebook, Twitter, Line dan media sosial lainnya yang berkembang ke seluruh dunia, termasuk di Indonesia (Dharma dan Sukaatmadja, 2015).

Fenomena tingginya pengguna smartphone ini membuat banyak perusahaan kian berkompetisi untuk meluncurkan produk-produk terbaiknya dalam memenuhi kebutuhan dan keinginan konsumen yang mengikuti permintaan pasar. Bukan hanya meluncurkan yang terbaik, namun masing-masing perusahaan dituntut untuk memiliki spesifikasi didalam produknya sehingga dapat tetap hidup dan bersaing dipasaran. Persepsi konsumen telah berubah mengenai kegiatan 
pemasaran. Sekarang, konsumen lebih sadar dan informasi tentang merek mereka telah ditawarkan karena persaingan terbuka di pasar (Babu, 2014). Beberapa merek smartphone yang bersaing dalam bisnis ini di Indonesia, seperti Samsung, Apple, Nokia, BlackBerry, Sony Ericsson, Oppo, dan Evercross.

Kemajuan teknologi saat ini yang makin berkembang dari waktu ke waktu, membuat produk-produk yang dibuat oleh produsen semakin beraneka ragam dan memiliki keunggulannya tersendiri. Persaingan kompetitif yang dilakukan oleh para produsen ini memberikan dampak yang positif bagi konsumen, tersedianya berbagai produk baru dengan fitur beragam. Memperhatikan harga suatu produk merupakan salah satu strategi perusahaan dalam menarik perhatian para konsumen. Konsumen akan menggunakan penilaian mereka dalam menentukan dan membuat keputusan mereka, terutama saat membeli produk yang berkualitas (Ackaradejruangsri, 2013).

Banyaknya perusahaan smartphone yang menembus pasar di Indonesia saat ini dan nama iPhone yang menjadi pesaing terbesar dipasar smartphone. Meskipun iPhone berada diposisi kedua setelah Samsung yaitu sebesar 13,9 persen (International Data Corporation, 2015), hal ini menarik untuk diteliti lebih lanjut karena dengan harga yang relatif mahal, iPhone masih tetap bersaing dan mengalahkan produk smartphone lainnya, tidak terkecuali yang terjadi di Bali, khususnya Kota Denpasar.

Produk iPhone mempunyai banyak kelebihan dari para pesaingnya, untuk memperoleh produk iPhone memerlukan biaya yang dikatakan mahal. Meskipun iPhone terkenal mahal, banyak orang yang tetap membeli produk tersebut. Hal itu 
dikarenakan iPhone merupakan merek yang sudah dikenal dari segi citra mereknya sendiri oleh banyak masyarakat sehingga mereka tetap membeli produk tersebut (Chrisandi, 2014).

Pada tahun 2017 iPhone mengalami penurunan market share dimana produk iPhone menempati tempat kedua setelah Samsung. Samsung mengalami peningkatan market share sebesar 5 persen dari tahun 2016 sampai tahun 2017, sedangkan iPhone mengalami penurunan sebesar 3,3 persen dari tahun sebelumnya (IDC, 2017). Hal ini menunjukan bahwa iPhone tidak bisa mempertahankan market share dibandingkan Samsung. Berdasarkan persentase yang menunjukkan bahwa iPhone kini mengalami penurunan market share, maka penelitian ini akan mengevaluasi faktor-faktor yang mempengaruhi niat pembelian konsumen terhadap produk iPhone. Berikut tabel market share smartphone tahun 2017 :

Tabel 1.

Market Share Smartphone Tahun 2017

\begin{tabular}{ccccccc}
\hline Period & Samsung & iPhone & Huawei & Xiaomi & Oppo & Others \\
\hline 2016Q4 & $18,3 \%$ & $18,0 \%$ & $10,6 \%$ & $3,3 \%$ & $7,3 \%$ & $42,5 \%$ \\
$2017 \mathrm{Q} 1$ & $23,3 \%$ & $14,7 \%$ & $10,6 \%$ & $4,3 \%$ & $7,5 \%$ & $40,2 \%$ \\
$2017 \mathrm{Q} 2$ & $22,9 \%$ & $11,8 \%$ & $10,0 \%$ & $6,2 \%$ & $8,0 \%$ & $40,0 \%$ \\
$2017 \mathrm{Q} 3$ & $22,1 \%$ & $12,4 \%$ & $11,1 \%$ & $7,5 \%$ & $8,1 \%$ & $39,5 \%$ \\
$2017 \mathrm{Q} 4$ & $19,8 \%$ & $19,7 \%$ & $10,7 \%$ & $7,2 \%$ & $6,9 \%$ & $36,6 \%$ \\
\hline
\end{tabular}

Sumber : IDC, 2017

Tingginya niat pembelian konsumen terhadap produk smartphone yang ditawarkan perusahaan merupakan harapan dari setiap perusahaan. Tingginya niat pembelian yang dilakukan konsumen mengakibatkan meningkatnya keuntungan yang diperoleh perusahaan semakin besar, sedangkan jika tingkat niat pembelian produk smartphone rendah, maka pendapatan yang diterima perusahaan akan 
menurun sehingga perusahaan kesulitan untuk memenuhi biaya operasionalnya, sehingga perusahaan harus melakukan strategi penjualan yang tepat meliputi harga dan brand image yang baik (Purnamasari dan Murwatiningsih 2015).

Harga adalah sebagai salah satu faktor yang memiliki pengaruh signifikan terhadap niat pembelian konsumen (Zhafira et al., 2013). Menurut Kenesei dan Todd (2003) dalam penelitiannya mengatakan, harga secara konsisten dinyatakan sebagai faktor yang utama mempengaruhi dalam niat pembelian. Jika harga rendah maka permintaan produk yang ditawarkan meningkat dan jika harga produk semakin tinggi maka permintaan produk semakinrendah. Konsumen dalam melakukan pembelian, harga secara konsisten dinyatakan sebagai faktor yang mempengaruhi niat pembelian yang utama. Berbeda dengan penelitian Widianto (2009) menyatakan bahwa harga tidak memiliki pengaruh yang signifikan terhadap niat pembelian konsumen.

Citra merek atau brand image merupakan penentu yang sangat berpengaruh terhadap pelanggan sehingga memiliki persepsi subjektif dan perilaku yang konsekuen (Ryu et al., 2008) dan merupakan isyarat ekstrinsik ketika konsumen mengevaluasi produk atau layanan sebelum membeli (Zeithaml, 1988). Konsumen mempertimbangkan konsekuensinya dari perilaku alternatif sebelum terlibat didalamnya (Banget al., 2000). Keller (2003) mendefinisikan citra merek sebagai persepsi tentang merek yang tercermin dari asosiasi merek yang ada dipikiran konsumen. Sebuah asosiasi merek memiliki tingkat kekuatan, dan link ke sebuah merek akan lebih kuat bila link berdasarkan pengalaman konsumen (Aaker, 1991). Asosiasi merek diklasifikasikan ke dalam tiga kategori termasuk atribut, manfaat, 
dan sikap dan asosiasi ini dapat bervariasi berdasarkan kesukaan mereka, kekuatan, dan keunikan (Keller, 2003).

Untuk membangun citra merek yang kuat, sebuah produk harus mengembangkan citra merek tersendiri yang membedakan dirinya dari pesaing dan mengkomunikasikan manfaat utama produk untuk target pelanggan (Lien, 2015). Konsumen cenderung untuk membeli produk dan jasa dengan nama-nama yang mempunyai citra merek yang baik. Semakin baiknya citra merek, semakin positif sikap konsumen terhadap merek dan atributnya (Aghekyanet al.,2012). Citra merek membantu konsumen dalam mengenali kebutuhan dan keinginan mengenai merek dan membedakan merek dari saingan lainnya (Anwaret al., 2011).

Brand image yang positif mempunyai pengaruh yang positif pada niat pembelian, semakin tinggi brand image yang diciptakan oleh perusahaan maka tingkat niat untuk membeli juga semakin meningkat (Suciningtyas, 2012). Wahyuni dan Suparna (2014) mengatakan bahwa brand image berpengaruh positif terhadap niat pembelian produk tas tiruan di Kota Denpasar. Mendrofa (2010) juga mengatakan bahwa brand image secara umum memiliki pengaruh positif terhadap niat pembelian pada produk laptop merek HP di Surabaya. Berbeda dengan penelitian yang dilakukan oleh Saeed et al. (2013) yang menyimpulkan bahwa konsumen di Pakistan tidak memperhatikan brand image dalam membeli produk pakian, karena orang di Pakistan tidak terpengaruh oleh dampak lingkungan. Mereka memilih merek sesuai dengan pilihan mereka sendiri dan tidak mengikuti perubahan lingkungan. 
Pada umumnya, konsumen yang ingin melakukan pembelian sebuah produk selalu mencari pengenalan produk yang tujuannya untuk melakukan perbandingan dan melakukan tinjauan langsung sesuai dengan bentuk promosi yang menjadi informasi bagi konsumen dalam mengambil sebuah keputusan (Kotler,2009:184).

Berdasarkan identifikasi masalah, maka tujuan dari penelitian ini adalah untuk menjelaskan pengaruh harga terhadap brand image produk iPhone di Kota Denpasar, untuk menjelaskan pengaruh harga dan brand image terhadap niat pembelian konsumen pada produk iPhone di Kota Denpasar, dan menjelaskan peran brand image dalam memediasi pengaruh harga terhadap niat pembelian pada produk iPhone di kota Denpasar.

Dahmiri (2009) dalam penelitiannya menyatakan bahwa harga berpengaruh signifikan terhadap citra Ramayana Department Store. Penelitian tersebut sepemikiran dengan penelitian yang dilakukan oleh Noerchoidah (2013) yang menyatakan bahwa harga dapat mempengaruhi brand image secara signifikan. Begitupun dengan penelitian yang dilakukan oleh Falihah (2013) yang menyatakan bahwa harga berpengaruh signifikan terhadap brand image, maka hipotesis sebagai berikut:

$\mathrm{H}_{1}$ : Harga berpengaruh secara positif dan signifikan terhadap brand image

Dalam penelitian yang ditulis oleh Nugroho (2010) menyebutkan bahwa harga menjadi pertimbangan yang penting saat konsumen akan melakukan pembelian. Menurut Alviolita (2015) harga yang terbentuk akan mempengaruhi niat pembelian konsumen pada suatu produk, Semakin terjangkaunya harga niat pembelian akan semakin meningkat. Mandasari (2011) dalam penelitiannya 
menyatakan faktor harga berpengaruh positif signifikan terhadap niat pembelian konsumen dalam memilih jasa perhotelan. Kenesi dan todd (2003) menyebutkan bahwa harga secara konsisten dinyatakan sebagai faktor utama yang mempengaruhi niat pembelian. Dalam penelitian Prisatrio (2009) juga menyatakan harga menjadi pertimbangan penting dan mempunyai pengaruh positif terhadap niat pembelian, maka hipotesis sebagai berikut:

$\mathrm{H}_{2}$ : Harga berpengaruh positif dan signifikan terhadap niat pembelian.

Mendrofa (2010) dalam penelitiannya menyatakan secara umum brand image berpengaruh positif terhadap niat pembelian. Heriyati dan septi (2013) dalam penelitiannya menyatakan terdapat pengaruh yang signifikan antara variable brand image terhadap variable niat pembelian pada handphone Nexian. Wang and Tsai (2014) dalam penelitiannya mengatakan bahwa brand image memang meningkatkan niat pembelian. Wahyuni dan Suparna (2014) mengatakan bahwa brand image berpengaruh positif dan signifikan terhadap niat pembelian produk tas tiruan di Kota Denpasar. Musay (2013) mendapatkan hasil yang sama dengan yang menyatakan bahwa brand image berpengaruh positif dan signifikan terhadap niat pembelian. Ini menunjukkan bahwa semakin positif brand image maka semakin tinggi intensi pembelian konsumen. Berdasarkan hasil-hasil penelitian yang telah dijelaskan diatas, maka hipotesis sebagai berikut:

$\mathrm{H}_{3}$ : Brand image berpengaruh positif dan signifikan terhadap niat pembelian.

Purnamasari dan Murwatiningsih (2015) dalam penelitiannya menunjukkan bahwa harga berpengaruh langsung terhadap niat pembelian melalui brand image. Fianto (2014) mendapatkan hasil analisis menunjukkan bahwa citra merek 
memiliki pengaruh positif dan signifikan terhadap prilaku niat membeli dikalangan mahasiswa perguruan islam swasta di Jawa Timur Indonesia. Berbeda dengan penelitian Ranto (2014) yang menyatakan citra merek tidak berpengaruh signifikan terhadap niat pembelian produk UKM di Yogyakarta. Hal ini menunjukkan bahwa brand image merupakan jalur untuk meningkatkan niat pembelian pada pengaruh harga terhadap niat pembelian. Berdasarkan hasil-hasil penelitian yang telah dijelaskan diatas, maka hipotesis sebagai berikut:

$\mathrm{H}_{4}$ : Brand image secara signifikan memediasi pengaruh harga terhadap niat pembelian.

Berdasarkan penelusuran pada kajian pustaka dan hasil-hasil penelitian sebelumnya maka model penelitian ini dapat digambarkan seperti Gambar 1 berikut :

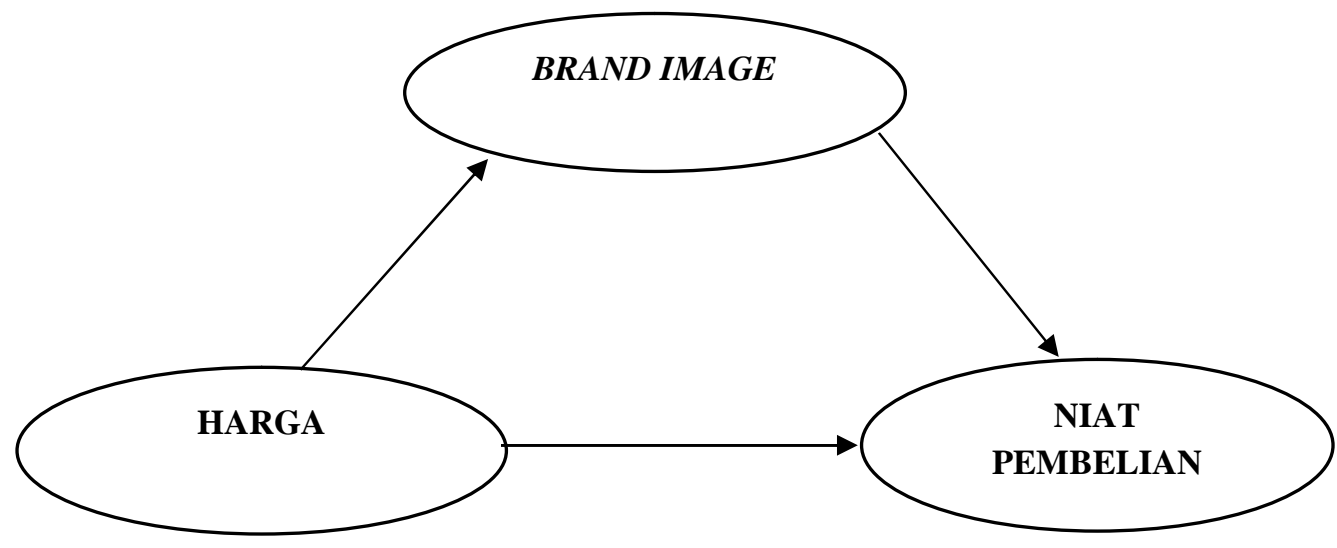

\section{Gambar 1. Model Kerangka Berfikir}

Sumber: Konsep yang dikembangkan dalam penelitian ini, 2018

\section{METODE PENELITIAN}

Pendekatan yang digunakan pada penelitian ini adalah pendekatan kuantitatif. Persepsi responden merupakan data kualitatif yang akan diukur dengan suatu skala sehingga hasilnya berbentuk angka. Selanjutnya angka atau skor tersebut diolah dengan metode statistik. Pengukuran metode ini adalah untuk mempermudah proses analisis data. 
Penelitian ini berbentuk penelitian asosiatif dengan tipe kausalitas. Penelitian yang berbentuk asosiatif dengan tipe kausalitas adalah penelitian yang menjelaskan pengaruh variable independen terhadap variable dependen (Sugiyono, 2011). Penelitian ini dilakukan untuk mengetahui pengaruh secara langsung dan tidak langsung dari tiap variabel yang diteliti yaitu peran brand imagedalam memediasi pengaruh harga terhadap niat pembelian.

Lokasi penelitian yang dipilih oleh peneliti terletak di Kota Denpasar. Berdasarkan Bali.bps.go.id (2015), Kota Denpasar sebagai pusat kota sekaligus ibu kota Provinsi Bali memiliki pertumbuhan perekonomian dan penduduk tertinggi yang mencerminkan gaya hidup masyarakat Bali yang update akan kebutuhan produk-produk baru, terutama produk elektronik konsumen yang dapat membantu pekerjaan masyarakat Kota Denpasar. Dengan demikian penduduk Kota Denpasar memiliki kemampuan untuk membeli produk dengan harga menegah keatas atau dapat dikatakan canggih dengan kualitas yang lebih baik seperti produk iPhone.

Tabel 2.

\section{Identifikasi Variabel}

\begin{tabular}{|c|c|c|}
\hline VARIABEL & INDIKATOR VARIABEL & REFERENSI \\
\hline Harga $(X)$ & $\begin{array}{l}\text { 1. Kesesuaian harga dengan spesifikasi produk yang } \\
\text { akan dibeli. } \\
\text { 2. Kesesuaian harga dengan tampilan produk yang } \\
\text { akan dibeli. } \\
\text { 3. Harga yang kompetitif. } \\
\text { 4. Kesuaian harga dengan fasilitas produk yang } \\
\text { didapat. }\end{array}$ & Stanton (1989) \\
\hline $\begin{array}{l}\text { Brand image } \\
\text { (M) }\end{array}$ & $\begin{array}{l}\text { 1. Sincerity, dimensi ini meliputi merek yang } \\
\text { dianggap jujur, apa adanya dan dianggap tidak } \\
\text { membodohi konsumen. } \\
\text { 2. Excitement, merek dianggap berani, bersemangat, } \\
\text { imajinatif dan selalu ada teknologi yang baru. } \\
\text { 3. Sophistication, merek yang dianggap canggih. } \\
\text { 4. Reputation, merek yang dianggap mempunyai } \\
\text { reputasi yang baik. }\end{array}$ & $\begin{array}{l}\text { Shimp (2010) dan } \\
\text { Aaker (1997) }\end{array}$ \\
\hline $\begin{array}{l}\text { Niat } \\
\text { Pembelian } \\
\text { (Y) }\end{array}$ & $\begin{array}{l}\text { 1. Saya tertarik untuk membeli produk iPhone. } \\
\text { 2. Saya tertarik untuk menggunakan produk iPhone. } \\
\text { 3. Saya ingin memiliki produk iPhone. }\end{array}$ & $\begin{array}{l}\text { Ling et al. (2010), } \\
\text { Wahyuni (2014) dan } \\
\text { Stephanie, et al. }(2013)\end{array}$ \\
\hline
\end{tabular}


Objek dalam penelitian ini adalah peran brand image dalam memediasi pengaruh harga produk terhadap niat pembelian produk iPhone di Kota Denpasar. Populasi dalam penelitian ini adalah konsumen yang akan menggunakan iPhone. Metode penentuan sampel dalam penelitian ini menggunakan teknik nonprobability sampling, dengan metode porpusive sampling yakni teknik penentuan sampel dengan pertimbangan tertentu. Adapun kriteria yang digunakan dalam peilihan sampel, yaitu: responden dengan usia 18-50 tahun, berpendidikan minimal SMA atau sederajat, berniat untuk melakukan pembelian iPhone dan bertempat tinggal di Kota Denpasar. Jumlah sampel yang direkomendasikan adalah 5-10 kali jumlah variabel atau indikator. Ferdinand, (2002:47) jumlah indikator dalam penelitian ini adalah 11 indikator dan jumlah sampel yang ditentukan sebanyak 100-200 sampel. Jadi dari nilai akhir antara nilai 5-10 maka jumlah sampel yang digunakan adalah $11 \times 10=110$ sampel.

Pada penelitian ini digunakan teknik analisis data berupa teknik analisis jalur atau disebut sebagai Path Analysis. Teknik analisis jalur ini akan digunakan dalam menguji besarnya kontribusi yang dinyatakan oleh koefisien jalur pada setiap diagram jalur dari hubungan kausal atau sebab akibat yang tercipta dari variabel eksogen terhadap variabel endogen. Berdasarkan pemaparan diatas maka persamaan struktural koefisien jalur dari penelitian ini adalah sebagai berikut :

$$
\begin{aligned}
& \mathrm{M}=\beta_{1} \mathrm{X}+\mathrm{e} \\
& \mathrm{Y}=\beta_{1} \mathrm{X}+\beta_{2} \mathrm{M}+\mathrm{e}
\end{aligned}
$$

Keterangan :

$\mathrm{Y} \quad=$ Niat Pembelian

$\mathrm{X}=\mathrm{Harga}$

$\mathrm{M}=$ Brand Image 
$\beta_{1}, \beta_{2}=$ koefisien regresi variabel

$\mathrm{e} \quad=$ error

\section{HASIL DAN PEMBAHASAN}

Karakteristik responden pada penelitian ini, dapat dilihat dari beberapa kriteria yaitu: jenis kelamin, umur, pendidikan terakhir, dan rata-rata pendapatan atau uang saku per bulan. Berikut disajikan karakteristik responden dari penelitian ini.

Tabel 3.

Karakteristik Responden Menurut Jenis kelamin

\begin{tabular}{cccc}
\hline \multirow{2}{*}{ Karakteristik } & Klasifikasi & Jumlah & Persentase \\
\cline { 3 - 4 } Jenis Kelamin & Laki-laki & (Orang) & $(\%)$ \\
& Perempuan & 62 & 43,64 \\
& Total & 110 & 56,36 \\
\multirow{4}{*}{ Umur } & $17-26$ Tahun & 47 & 100 \\
& $27-36$ Tahun & 29 & 42,72 \\
& $37-46$ Tahun & 18 & 26,36 \\
& $\geq 47$ Tahun & 16 & 16,36 \\
Pendidikan & Total & 110 & 14,55 \\
Terakhir & SMA & 33 & 100 \\
& Diploma & 24 & 30,00 \\
& Sarjana / Pasca Sarjana & 54 & 21,82 \\
& Lainnya & 2 & 46,36 \\
Pendapatan & Total & 110 & 1,82 \\
per bulan & Rp. $1.000 .000-$ Rp. 3.000 .000 & 21 & 100 \\
& $>$ Rp. 3.000 .000 & 40 & 19,09 \\
& Total & 49 & 36,36 \\
& Rp. 1.000 .000 & 110 & 44,55 \\
\hline
\end{tabular}

Sumber: Data primer diolah, 2017

Tabel 3 menunjukkan jumlah responden berjenis kelamin perempuan sebanyak 62 orang (56,36 persen), dan jumlah responden berjenis kelamin lakilaki sebanyak 48 orang (43,64 persen). Data menunjukkan berdasarkan umur responden dapat diketahui bahwa jumlah responden yang berumur 17-26 tahun sebanyak 47 orang (42,72 persen), jumlah responden yang berumur 27-36 tahun sebanyak 29 orang (26,36 persen), jumlah responden yang berumur 37-46 tahun 
sebanyak 18 orang (16,36 persen), dan jumlah responden yang berumur lebih dari 47 tahun sebanyak 16 orang (14,55 persen).

Tabel 3 menjelaskan bahwa jumlah responden berdasarkan pendidikan terakhir Sarjana/Pasca Sarjana sebanyak 54 orang (46,36 persen), responden berdasarkan pendidikan terakhir SMA sebanyak 33 orang (30 persen), responden berdasarkan pendidikan terakhir Diploma sebanyak 24 orang (21,82 persen), dan responden berdasarkan pendidikan terakhir lainnya sebanyak 2 orang $(1,82$ persen). Hal ini menunjukkan bahwa mayoritas responden dalam penelitian ini adalah yang memiliki tingkat pendidikan akhir yaitu Sarjana/Pasca Sarjana dengan jumlah sebanyak 51 orang (46,36 persen). Data menunjukkan bahwa jumlah responden dengan jumlah pendapatan lebih dari Rp. 3.000.000 sebanyak 49 orang (44,55 persen), responden dengan jumlah pendapatan Rp. $1.000 .000-$ Rp. 3.000.000 sebanyak 40 orang (36,36 persen), responden dengan jumlah pendapatan kurang dari Rp. 1.000 .000 sebanyak 21 orang (19,09 persen). Hasil survei dari penelitian ini menunjukan bahwa responden sebagian besar memiliki pendapatan lebih dari Rp. 3.000.000.

Instrumen dalam penelitian ini diuji menggunakan uji validitas dan uji reliabilitas. Suatu instrumen dikatakan valid apabila memiliki koefisien korelasi antara butir dengan skor total dalam instrumen tersebut lebih besar dari 0,30 dengan tingkat kesalahan Alpha 0,05. Tabel 4 berikut menyajikan hasil uji validitas instrumen penelitian. 
Tabel 4.

Rekapitulasi Hasil Uji Validitas Instrumen Penelitian

\begin{tabular}{|c|c|c|c|c|c|}
\hline No & Variabel & $\begin{array}{c}\text { Item } \\
\text { Pernyataan }\end{array}$ & $\begin{array}{l}\text { Korelasi } \\
\text { Item }\end{array}$ & $\begin{array}{l}\text { Sig. }(2- \\
\text { tailed) }\end{array}$ & Keterangan \\
\hline \multirow{4}{*}{1} & \multirow{4}{*}{$\begin{array}{l}\text { Harga } \\
\text { (X) }\end{array}$} & $\mathrm{X}_{1}$ & 0,862 & 0,000 & Valid \\
\hline & & $\mathrm{X}_{2}$ & 0,779 & 0,000 & Valid \\
\hline & & $\mathrm{X}_{3}$ & 0,785 & 0,000 & Valid \\
\hline & & $\mathrm{X}_{4}$ & 0,808 & 0,000 & Valid \\
\hline \multirow{4}{*}{2} & \multirow{4}{*}{$\begin{array}{l}\text { Brand Image } \\
\text { (M) }\end{array}$} & $\mathrm{M}_{1}$ & 0,597 & 0,000 & Valid \\
\hline & & $\mathrm{M}_{2}$ & 0,770 & 0,000 & Valid \\
\hline & & $\mathrm{M}_{3}$ & 0,713 & 0,000 & Valid \\
\hline & & $\mathrm{M}_{4}$ & 0,732 & 0,000 & Valid \\
\hline \multirow{3}{*}{3} & \multirow{3}{*}{$\begin{array}{c}\text { Niat } \\
\text { Pembelian } \\
\text { (Y) }\end{array}$} & $\mathrm{Y}_{1}$ & 0,723 & 0,000 & Valid \\
\hline & & $\mathrm{Y}_{2}$ & 0,800 & 0,004 & Valid \\
\hline & & $\mathrm{Y}_{3}$ & 0,710 & 0,000 & Valid \\
\hline
\end{tabular}

Sumber : Data primer diolah, 2017

Hasil uji validitas pada tabel 4 menunjukkan bahwa seluruh instrumen penelitian yang digunakan untuk mengukur variabel harga, brand image, dan niat pembelian memiliki nilai koefisien korelasi dengan skor total seluruh item pernyataan lebih besar dari 0,30 dengan signifikansi kurang dari 0,05. Hal ini menunjukkan bahwa butir-butir pernyataan dalam instrument penelitian tersebut valid dan layak digunakan sebagai instrument penelitian.

Uji Reliabilitas terhadap instrumen penelitian ini menggunakan nilai Alpha Cronbach, yakni untuk mengetahui unidimensionalitas butir-butir pernyataan terhadap variabel laten yang diteliti (harga, brand image, dan niat pembelian). Nilai Alpha Cronbach dinyatakan reliabel jika nilainya lebih besar atau sama dengan 0,60. Rekapitulasi hasil uji reliabilitas instrumen penelitian dapat dilihat pada Tabel 5 berikut. 
Tabel 5.

Rekapitulasi Hasil Uji Reliabilitas Instrumen Penelitian

\begin{tabular}{clcc}
\hline No. & \multicolumn{1}{c}{ Variabel } & Cronbach's Alpha & Keterangan \\
\hline $\mathbf{1}$ & Harga $(\mathrm{X} 1)$ & 0,817 & Reliabel \\
$\mathbf{2}$ & Brand Image $(\mathrm{Y} 1)$ & 0,774 & Reliabel \\
$\mathbf{3}$ & Niat Pembelian $(\mathrm{Y} 2)$ & 0,799 & Reliabel \\
\hline
\end{tabular}

Sumber : Data primer diolah, 2017

Hasil uji reliabilitas yang disajikan dalam Tabel 5 menunjukkan bahwa seluruh instrumen penelitian memiliki koefisien Cronbach's Alpha lebih dari 0,60. Jadi dapat dinyatakan bahwa seluruh variabel telah memenuhi syarat reliabilitas atau kehandalan sehingga dapat digunakan untuk melakukan penelitian.

Variabel harga dalam penelitian ini merupakan variabel bebas yang diukur dengan menggunakan 4 pernyataan yang berhubungan dengan harga iPhone di Kota Denpasar. Secara rinci hasil penelitian mengenai persepsi responden terhadap variabel harga disajikan pada Tabel 6.

Tabel 6.

Deskripsi Jawaban Responden Pada Variabel Harga

\begin{tabular}{|c|c|c|c|c|c|c|c|c|}
\hline \multirow[t]{2}{*}{ No } & \multirow{2}{*}{ Pernyataan } & \multicolumn{5}{|c|}{$\begin{array}{c}\text { Frekuensi Jawaban Responden } \\
\text { (orang) }\end{array}$} & \multirow{2}{*}{$\begin{array}{l}\text { Rata- } \\
\text { Rata }\end{array}$} & \multirow{2}{*}{ Kriteria } \\
\hline & & STS & TS & $\mathbf{N}$ & $\mathbf{S}$ & SS & & \\
\hline 1 & $\begin{array}{l}\text { Menurut saya harga iPhone } \\
\text { sesuai dengan spesifikasinya. }\end{array}$ & 0 & 6 & 20 & 50 & 34 & 4,02 & Tinggi \\
\hline 2 & $\begin{array}{l}\text { Menurut saya harga iPhone } \\
\text { sesuai dengan tampilannya. }\end{array}$ & 1 & 6 & 11 & 59 & 33 & 4,06 & Tinggi \\
\hline 3 & $\begin{array}{l}\text { Menurut saya harga iPhone } \\
\text { kompetitif. }\end{array}$ & 0 & 4 & 20 & 63 & 23 & 3,95 & Tinggi \\
\hline 4 & $\begin{array}{l}\text { Menurut saya harga iPhone } \\
\text { sesuai dengan fasilitas yang } \\
\text { ditawarkan. }\end{array}$ & 1 & 4 & 12 & 53 & 40 & 4,15 & Tinggi \\
\hline \multicolumn{7}{|c|}{ Rata-rata keseluruhan variabel Harga } & 4,05 & Tinggi \\
\hline
\end{tabular}

Sumber : Data primer diolah, 2017

Hasil analisis deksriptif sebagaimana disajikan pada tabel 6 menunjukkan skor rata-rata Harga sebesar 4,05. Dari 4 indikator yang digunakan untuk mengukur harga, maka terdapat 2 indikator yang nilainya berada diatas nilai rata- 
rata $(4,05)$ variabel harga yaitu indikator kesesuaian harga dengan tampilan produk yang akan dibeli dan kesuaian harga dengan fasilitas produk yang didapat. Indikator kesuaian harga dengan fasilitas produk yang didapat memiliki nilai paling tinggi jika dibandingkan dengan indikator lainnya. Hal tersebut menandakan bahwa fasilitas yang diberikan iPhone dianggap sesuai dengan harga yang ditawarkan.

Variabel brand image dalam penelitian ini merupakan variabel mediasi yang diukur dengan menggunakan 4 pernyataan yang berhubungan dengan brand image iPhone di Kota Denpasar. Secara rinci hasil penelitian mengenai persepsi responden terhadap variabel brand image disajikan pada Tabel 7 berikut.

Tabel 7.

Deskripsi Jawaban Responden pada Variabel Brand Image

\begin{tabular}{|c|c|c|c|c|c|c|c|c|}
\hline \multirow[t]{2}{*}{ No } & \multirow[t]{2}{*}{ Pernyataan } & \multicolumn{5}{|c|}{$\begin{array}{c}\text { Frekuensi Jawaban Responden } \\
\text { (orang) }\end{array}$} & \multirow{2}{*}{$\begin{array}{c}\text { Rata } \\
- \\
\text { Rata }\end{array}$} & \multirow[t]{2}{*}{ Kriteria } \\
\hline & & STS & TS & $\mathbf{N}$ & $\mathbf{S}$ & SS & & \\
\hline 1 & $\begin{array}{l}\text { Menurut saya produk iPhone dapat } \\
\text { dipercaya. }\end{array}$ & 0 & 3 & 24 & 55 & 28 & 3,98 & Baik \\
\hline 2 & $\begin{array}{l}\text { Menurut saya produk iPhone } \\
\text { selalu melakukan inovasi terbaru. }\end{array}$ & 0 & 6 & 20 & 64 & 20 & 3,89 & Baik \\
\hline 3 & $\begin{array}{l}\text { Menurut saya produk iPhone } \\
\text { merupakansmartphone yang } \\
\text { canggih. }\end{array}$ & 0 & 4 & 24 & 58 & 24 & 3,93 & Baik \\
\hline 4 & $\begin{array}{l}\text { Menurut saya produk iPhone } \\
\text { memiliki reputasi yang baik. }\end{array}$ & 1 & 4 & 8 & 61 & 36 & 4,15 & Baik \\
\hline \multicolumn{7}{|c|}{ Rata-rata keseluruhan variabel Brand Image } & 3,98 & Baik \\
\hline
\end{tabular}

Sumber : Data primer diolah, 2017

Hasil analisis deksriptif sebagaimana disajikan pada tabel 7 menunjukkan skor rata-rata brand image sebesar 3,98, yang berarti bahwa iPhone mempunyai citra merek yang baik di mata Konsumen. Dari 4 indikator yang digunakan untuk mengukur brand image, terdapat 1 indikator yang nilainya berada diatas nilai rata- 
rata $(3,98)$ variabel brand image yaitu indikator reputasi. Hal ini dapat diartikan bahwa konsumen menganggap iPhone mempunyai reputasi yang baik.

Variabel terikat dalam penelitian ini diukur dengan menggunakan 3 pernyataan yang berhubungan dengan niat pembelian produk iPhone di kota Denpasar. Secara rinci hasil penelitian mengenai persepsi responden terhadap variabel niat pembelian disajikan pada Tabel 8 berikut.

Tabel 8.

Deskripsi Jawaban Responden pada Variabel Niat Pembelian

\begin{tabular}{|c|c|c|c|c|c|c|c|c|}
\hline \multirow{2}{*}{ No } & \multirow{2}{*}{ Pernyataan } & \multicolumn{5}{|c|}{$\begin{array}{c}\begin{array}{c}\text { Frekuensi Jawaban Responden } \\
\text { (Orang) }\end{array} \\
\end{array}$} & \multirow{2}{*}{$\begin{array}{l}\text { Rata- } \\
\text { Rata }\end{array}$} & \multirow{2}{*}{ Kriteria } \\
\hline & & STS & TS & $\mathbf{N}$ & $\mathbf{S}$ & SS & & \\
\hline 1 & $\begin{array}{l}\text { Saya tertarik untuk membeli } \\
\text { produk iPhone. }\end{array}$ & 0 & 4 & 16 & 63 & 27 & 4,03 & Tinggi \\
\hline 2 & $\begin{array}{lr}\text { Saya tertarik } & \text { untuk } \\
\text { menggunakan } & \text { produk } \\
\text { iPhone. } & \end{array}$ & 0 & 8 & 21 & 61 & 20 & 3,85 & Tinggi \\
\hline 3 & $\begin{array}{l}\text { Saya tertarik untuk memiliki } \\
\text { produk iPhone. }\end{array}$ & 0 & 7 & 11 & 54 & 38 & 4,12 & Tinggi \\
\hline \multicolumn{7}{|c|}{ Rata-rata keseluruhan variabel Niat Pembelian } & 3,99 & Tinggi \\
\hline
\end{tabular}

Sumber : Data primer diolah, 2017

Hasil analisis deksriptif sebagaimana disajikan pada tabel 8 menunjukkan skor rata-rata niat pembelian sebesar 3,99, yang berarti bahwa sebagian besar konsumen memiliki niat yang tinggi untuk membeli produk iPhone di kota Denpasar. Dari 3 indikator yang digunakan untuk mengukur niat pembelian, maka terdapat 2 indikator yang nilainya berada di atas nilai rata-rata $(3,99)$ variabel niat pembelian yaitu indikator tertarik untuk membeli produk iPhone dan ingin memiliki produk iPhone. Indikator yang menyatakan tertarik untuk memiliki produk iPhone memiliki nilai paling tinggi jika dibandingkan dengan indikator lainnya. 
Sebelum melakukan analisis regresi, data harus diuji agar memenuhi asumsi dasar di dalam analisis regresi. Hasil uji asumsi klasik yang dilakukan dalam penelitian ini adalah uji normalitas, uji multikoliniearitas dan uji heteroskedastisitas. Uji normalitas bertujuan untuk mengetahui apakah residual dari model regresi yang dibuat berdistribusi normal atau tidak. Untuk menguji apakah data yang digunakan normal atau tidak dapat dilakukan dengan menggunakan uji Kolmogorov Sminarnov. Apabila koefisien Asymp. Sig. (2tailed) lebih besar dari 0,05 maka data tersebut dikatakan berdistribusi normal.

Tabel 9.

Hasil Uji Normalitas Struktur 1

\begin{tabular}{lc}
\hline & Unstandardized Residual \\
\hline $\mathrm{N}$ & 110 \\
Kolmogorov-Smirnov $Z$ & 0,956 \\
Asymp.Sig.(2-tailed) & 0,320 \\
\hline Sumber : Data primer diolah, 2017 &
\end{tabular}

Berdasarkan Tabel 9 dapat dilihat bahwa nilai Kolmogorov Sminarnov (KS) sebesar 0,956, sedangkan nilai Asymp. Sig. (2-tailed) sebesar 0,320. Hasil tersebut mengindikasikan bahwa model persamaan regresi tersebut berdistribusi normal karena nilai Asymp. Sig. (2-tailed) lebih besar dari nilai alpha 0,05.

Tabel 10.

Hasil Uji Normalitas Struktur 2

\begin{tabular}{lc}
\hline & Unstandardized Residual \\
\hline $\mathrm{N}$ & 110 \\
Kolmogorov-Smirnov $Z$ & 0,508 \\
Asymp.Sig.(2-tailed) & 0,959
\end{tabular}

Sumber : Data primer diolah, 2017

Berdasarkan Tabel 10 dapat dilihat bahwa nilai Kolmogorov Sminarnov (KS) sebesar 0,508, sedangkan nilai Asymp. Sig. (2-tailed) sebesar 0,959. Hasil tersebut mengindikasikan bahwa model persamaan regresi tersebut berdistribusi normal karena nilai Asymp. Sig. (2-tailed) lebih besar dari nilai alpha 0,05. 
Uji multikolinieritas bertujuan untuk menguji apakah pada model regresi ditemukan adanya korelasi antar variabel bebas. Adanya multikolinearitas dapat dilihat dari nilai tolerance atau variance inflation factor (VIF). Jika nilai tolerance lebih dari $10 \%$ atau VIF Kurang dari 10, maka dikatakan tidak ada multikolinearitas.

Tabel 11.

Hasil Uji Multikoleniaritas

\begin{tabular}{cccc}
\hline Persamaan Struktur & Variabel & Tolerance & VIF \\
\hline $\mathrm{M}=\beta_{1} \mathrm{X}+\mathrm{e}$ & Harga $(\mathrm{X})$ & 1,000 & 1,000 \\
\hline $\mathrm{Y}=\beta_{2} \mathrm{X}+\beta_{3} \mathrm{M}+\mathrm{e}$ & Harga $(\mathrm{X})$ & 0,784 & 1,276 \\
& Brand Image $(\mathrm{M})$ & 0,784 & 1,276 \\
\hline
\end{tabular}

Sumber : Data primer diolah, 2017

Berdasarkan Tabel 11 dapat dilihat bahwa nilai tolerance dan VIF dari variabel harga, dan brand image menunjukkan nilai tolerance untuk setiap variabel lebih besar dari $10 \%$ dan nilai VIF lebih kecil dari 10 yang berarti model persamaan regresi bebas dari multikolinearitas.

Uji heteroskedastisitas bertujuan untuk mengetahui apakah dalam model regresi terjadi ketidaksamaan varians dari residual satu pengamatan ke pengamatan yang lain dan pengujian ini dilakukan dengan uji Glejser. Jika nilai signifikansinya di atas 0,05 maka tidak mengandung gejala heteroskedastisitas.

Tabel 12. Hasil Uji Heteroskedastisitas Struktur 1

\begin{tabular}{|c|c|c|c|c|c|c|}
\hline \multirow{2}{*}{\multicolumn{2}{|c|}{ Model }} & Unstandardize & Coefficients & \multicolumn{3}{|l|}{ Standardized } \\
\hline & & $\mathrm{B}$ & Std. Error & $\frac{\text { Coefficients }}{\text { Beta }}$ & $\mathrm{t}$ & Sig. \\
\hline \multirow[t]{2}{*}{1} & (Constant) & 1.957 & .858 & & 2.281 & .025 \\
\hline & Harga & -.029 & .052 & -.054 & -.560 & .577 \\
\hline
\end{tabular}

Pada Tabel 12 dapat dilihat bahwa nilai signifikansi dari variabel harga sebesar 0,577. Nilai tersebut lebih besar dari 0,05 yang berarti tidak terdapat 
pengaruh antara variabel bebas terhadap absolute residual. Dengan demikian, model yang dibuat tidak mengandung gejala heteroskedastisitas.

Tabel 13.

Hasil Uji Heteroskedastisitas Struktur 2

\begin{tabular}{|c|c|c|c|c|c|c|}
\hline \multirow{2}{*}{\multicolumn{2}{|c|}{ Model }} & & Coffiniont & \multicolumn{3}{|l|}{ Standardized } \\
\hline & & $\mathrm{B}$ & Std. Error & $\frac{\text { Coefficients }}{\text { Beta }}$ & $\mathrm{t}$ & Sig. \\
\hline \multirow[t]{3}{*}{1} & (Constant) & 1.822 & .711 & & 2.563 & .012 \\
\hline & Harga & .011 & .042 & .027 & .253 & .801 \\
\hline & Brand Image & -.055 & .043 & -.136 & -1.260 & .210 \\
\hline
\end{tabular}

Pada Tabel 13 dapat dilihat bahwa nilai signifikansi dari variabel harga, dan brand image, masing-masing sebesar 0,801 dan 0,210. Nilai tersebut lebih besar dari 0,05 yang berarti tidak terdapat pengaruh antara variabel bebas terhadap absolute residual. Dengan demikian, model yang dibuat tidak mengandung gejala heteroskedastisitas.

Pengujian data dalam penelitian ini menggunakan teknik analisis jalur (Path Analysis), dimana analisis jalur adalah perluasan dari analisis regresi linear berganda untuk menguji hubungan kausalitas antara 2 atau lebih variabel. Perhitungan koefisien path dilakukan dengan analisis regresi melalui software SPSS 22.0 for Windows, diperoleh hasil yang ditunjukan pada Tabel 14 berikut.

Tabel 14.

Hasil Analisis Jalur 1

\begin{tabular}{lcccc}
\hline \multicolumn{1}{c}{ Variabel } & Unstandardized Beta & Std. Error & t hitung & Sig. uji t \\
\hline (Constant) & 8,747 & 1,333 & 6,561 & 0,000 \\
Harga (X) & 0,445 & 0,082 & 5,460 & 0,000 \\
R Square & 0,216 & & & \\
F Statistik & 29,807 & & & \\
Signifikansi Uji F & 0,000 & & & \\
\hline S & & &
\end{tabular}

Sumber: Data primer diolah, 2017

Berdasarkan hasil analisis jalur substruktur 1 seperti yang disajikan pada Tabel 14, maka dapat dibuat persamaan struktural sebagai berikut : 
$\mathrm{M}=8,747+0,445 \mathrm{X}+\mathrm{e}_{1}$

Nilai koefisien regresi variabel harga bernilai positif dengan nilai signifikansi uji t kurang dari 0,05 . Hal ini menunjukkan bahwa variabel harga memiliki pengaruh positif yang signifikan terhadap variabel brand image. Besarnya pengaruh variabel bebas terhadap variabel terikat yang ditunjukkan oleh nilai determinasi total (R Square) sebesar 0,216 mempunyai arti bahwa sebesar 21,6\% variasi brand image dipengaruhi oleh variasi harga, sedangkan sisanya sebesar 78,4\% dijelaskan oleh faktor lain yang tidak dimasukkan ke dalam model.

Tabel 15.

Hasil Analisis Jalur 2

\begin{tabular}{lcccc}
\hline \multicolumn{1}{c}{ Variabel } & Unstandardized Beta & Std. Error & t hitung & Sig. uji t \\
\hline (Constant) & 3,019 & 1,163 & 2,597 & 0,011 \\
Harga (X) & 0,191 & 0,068 & 2,814 & 0,006 \\
Brand Image (M) & 0,368 & 0,071 & 5,190 & 0,000 \\
R Square & 0,366 & & & \\
F Statistik & 30,907 & & & \\
Signifikansi Uji F & 0,000 & & & \\
\hline
\end{tabular}

Sumber : Data primer diolah, 2017

Berdasarkan hasil analisis jalur substruktur 2 seperti yang disajikan pada Tabel 15, maka dapat dibuat persamaan struktural sebagai berikut :

$$
\mathrm{Y}=3,019+0,191 \mathrm{X}+0,368 \mathrm{Y}+\mathrm{e}_{2}
$$

Nilai koefisien regresi masing-masing variabel bebas bernilai positif dengan nilai signifikansi uji t kurang dari 0,05 . Hal ini menunjukkan bahwa semua variabel bebas memiliki pengaruh positif yang signifikan terhadap variabel terikat. Besarnya pengaruh variabel bebas terhadap variabel terikat yang ditunjukkan oleh nilai determinasi total ( $\mathrm{R}$ Square) sebesar 0,366 mempunyai arti bahwa sebesar 36,6\% variasi niat pembelian dipengaruhi oleh variasi harga dan brand image, 
sedangkan sisanya sebesar $63,7 \%$ dijelaskan oleh faktor lain yang tidak dimasukkan ke dalam model.

Berdasarkan model substruktur 1 dan substruktur 2, maka dapat disusun model diagram jalur akhir. Sebelum menyusun model diagram jalur akhir, terlebih dahulu dihitung nilai standar eror sebagai berikut :

$$
\begin{aligned}
& \mathrm{Pe}_{\mathrm{i}}=\sqrt{1-\mathrm{R}_{\mathrm{i}}{ }^{2}} \ldots \ldots \ldots \ldots \ldots \ldots \ldots \ldots \ldots \ldots \ldots \ldots \ldots \ldots \\
& \mathrm{Pe}_{1}=\sqrt{1-{R_{1}}^{2}}=\sqrt{1-0,216}=0,885 \\
& \mathrm{Pe}_{2}=\sqrt{1-{R_{2}}^{2}}=\sqrt{1-0,366}=0,796
\end{aligned}
$$

Berdasarkan perhitungan pengaruh error (Pei), didapatkan hasil pengaruh error $\left(\mathrm{Pe}_{1}\right)$ sebesar 0,885 dan pengaruh error $\left(\mathrm{Pe}_{2}\right)$ sebesar 0,796. Hasil koefisien determinasi total adalah sebagai berikut :

$$
\begin{aligned}
\mathrm{R}^{2} \mathrm{~m} & =1-\left(\mathrm{Pe}_{1}\right)^{2}\left(\mathrm{Pe}_{2}\right)^{2} \\
& =1-(0,885)^{2}(0,796)^{2} \\
& =1-(0,783)(0,633) \\
& =1-0,495=0,505
\end{aligned}
$$

Nilai determinasi total sebesar 0,505 mempunyai arti bahwa sebesar 50,5\% variasi niat pembelian dipengaruhi oleh variasi harga dan brand image, sedangkan sisanya sebesar 49,5\% djelaskan oleh faktor lain yang tidak dimasukkan ke dalam model.

Pengujian pengaruh tidak langsung variabel harga $(\mathrm{X})$ terhadap variabel niat pembelian (Y) melalui variabel brand image (M), dalam penelitian ini menggunakan analisis Sobel dengan perhitungan sebagai berikut :

$$
\begin{aligned}
& S_{b 1 b 3}=\sqrt{(0,368)^{2}(0,082)^{2}+(0,445)^{2}(0,071)^{2}+(0,082)^{2}(0,071)^{2}} \\
& S_{b 1 b 3}=0,04407
\end{aligned}
$$


Untuk menguji signifikansi pengaruh tidak langsung maka menghitung nilai $\mathrm{z}$ dari koefisien ab dengan rumus sebagai berikut :

$$
\begin{aligned}
& Z=\frac{(0,445)(0,368)}{0,04407} \\
& Z=3,715 \text { dengan signifikansi } 0,0002
\end{aligned}
$$

Oleh karena $\mathrm{Z}$ hitung sebesar 3,715 > 1,96. Artinya brand image $(\mathrm{M})$ merupakan variabel yang memediasi harga $(\mathrm{X})$ terhadap niat pembelian $(\mathrm{Y})$ pada produk iPhone di Kota Denpasar atau dengan kata lain harga berpengaruh secara tidak langsung terhadap niat pembelian melalui brand image.

Hasil analisis menunjukkan bahwa harga berpengaruh positif dan signifikan terhadap brand image. Dengan demikian, harga yang sesuai akan mampu mendorong brand image yang positif terhadap produk iPhone, sebaliknya bila harga produk iPhone tidak sesuai dengan persepsi konsumen maka brand image produk iPhone akan negatif. Kesesuaian harga produk iPhone dengan spesifikasi produk iPhone yang ditawarkan mampu meningkatkan brand image produk iPhone dihadapan konsumen.

Selain itu harga produk iPhone yang sesuai dengan tampilan produk yang terlihat menarik mampu meningkatkan brand image produk iPhone dihadapan konsumen. Namun ada beberapa responden yang menyatakan harga produk iPhone kurang kompetitif dengan smartphone lainnya yang bisa menyebabkan brand image produk iPhone kurang baik dibenak konsumen. Kemudian, kesuaian harga dengan fasilitas produk yang didapat pada produk iPhone juga mampu meningkatkan brand image produk iPhone dihadapan konsumen. Fasilitas yang diberikan iPhone memang sesuai dengan harga yang ditawarkan. iPhone 
memberikan keamanan tingkat tinggi, sistem update iOS yang lebih baik, dan aplikasi yang canggih seperti iMessages, iCloud, FaceTime maupun beragam aplikasi lainnya bagi pengguna iPhone. Selain itu, pihak Apple juga memberikan informasi yang lebih lengkap baik itu dari produknya, tempat penjualan produk, panduan sampai juga dengan cara mengatasi iPhone yang error juga dibahas sangat detail. Penelitian ini mendukung beberapa hasil penelitian sebelumnya dan konsisten dengan hasil penelitian Dahmiri (2009), Noerchoidah (2013), dan Falihah (2013) yang menyatakan bahwa harga berpengaruh signifikan terhadap brand image.

Hasil analisis menunjukkan bahwa harga berpengaruh positif dan signifikan terhadap niat pembelian. Persepsi harga produk iPhone yang diterima dengan baik oleh konsumen, mampu mendorong niat konsumen untuk membeli produk iPhone, sebaliknya bila persepsi harga produk iPhone yang diterima tidak sesuai dengan keinginan konsumen maka niat konsumen untuk membeli produk iPhone akan semakin berkurang. Produk iPhone merupakan produk yang canggih sehingga dapat meningkatkan niat pembelian konsumen pada produk iPhone.

Kesesuaian harga produk iPhone dengan spesifikasi produk iPhone yang ditawarkan mampu menarik perhatian konsumen untuk membeli produk iPhone. Selain itu harga produk iPhone yang sesuai dengan tampilan produk yang terlihat canggih mampu membuat konsumen tertarik untuk menggunakan produk iPhone. Kemudian, kesuaian harga dengan fasilitas yang diberikan produk iPhone seperti sistem update iOS yang lebih baik, serta aplikasi yang terdiri dari iMessages, iCloud, FaceTime maupun beragam aplikasi lainnya mampu membuat konsumen 
tertarik untuk memiliki produk iPhone. Penelitian ini mendukung beberapa hasil penelitian sebelumnya dan konsisten dengan hasil penelitian Nugroho (2010), Alviolita (2015), Mandasari (2011), Kenesi dan todd (2003) serta Prisatrio (2009) yang menyatakan bahwa harga mempunyai pengaruh positif terhadap niat pembelian.

Hasil analisis menunjukkan bahwa brand image berpengaruh positif dan signifikan terhadap niat pembelian. Hal ini memiliki makna bahwa semakin baik brand image produk iPhone, maka akan semakin tinggi pula niat pembelian konsumen pada produk iPhone di Kota Denpasar. Begitu pula sebaliknya, semakin buruk brand image produk iPhone, maka akan semakin rendah pula niat pembelian konsumen pada produk iPhone di Kota Denpasar.

Produk iPhone yang dapat dipercaya oleh konsumen mampu menarik perhatian konsumen untuk membeli produk iPhone. Produk iPhone yang selalu melakukan inovasi produk terbaru yang mampu membuat konsumen tertarik untuk menggunakan produk iPhone. Selain itu, produk iPhone merupakan smartphone yang canggih, ini mampu membuat konsumen tertarik untuk memiliki produk iPhone. Konsumen menganggap iPhone mempunyai reputasi yang baik, khususnya karena Apple memiliki reputasi akan ponsel yang mempunyai brand image yang baik dan dirancang dengan baik, sehingga mampu mendorong niat konsumen untuk melakukan pembelian terhadap produk iPhone.

Penelitian ini mendukung beberapa hasil penelitian sebelumnya dan konsisten dengan hasil penelitian Mendrofa (2010), Heriyati dan seperti (2013), Wang and Tsai (2014), Wahyuni dan Suparna (2014), serta Musay (2013) yang 
mendapatkan hasil bahwa brand image berpengaruh positif dan signifikan terhadap niat pembelian. Ini menunjukkan bahwa semakin positif brand image maka semakin tinggi intensi pembelian konsumen.

Pengaruh harga terhadap niat pembelian akan lebih meningkat dengan adanya brand image yang baik. Niat pembelian produk iPhone di Kota Denpasar dipengaruhi oleh faktor-faktor harga yang terdiri dari kesesuaian harga dengan spesifikasi produk yang akan dibeli, kesesuaian harga dengan tampilan produk yang akan dibeli, harga yang kompetitif dan kesuaian harga dengan fasilitas produk yang ditawarkan diimbangi dengan adanya brand image yang baik. Persepsi pelanggan terhadap harga akan berpengaruh terhadap niat pembelian jika produk iPhone memiliki brand image yang baik. Hasil penelitian ini didukung oleh penelitian Purnamasari dan Murwatiningsih (2015), dan Fianto (2014) yang menemukan hasil bahwa brand image mampu memediasi pengaruh harga terhadap niat pembelian. Artinya, harga berpengaruh secara positif dan signifikan terhadap niat pembelian melalui brand image.

\section{SIMPULAN DAN SARAN}

Berdasarkan hasil analisis penelitian dan hasil pembahasan, maka dapat ditarik beberapa kesimpulan yaitu harga berpengaruh positif dan signifikan terhadap brand image produk iPhone di Kota Denpasar. Hal ini menunjukkan bahwa harga yang tinggi akan mampu mendorong brand image yang positif terhadap produk iPhone. Harga berpengaruh positif dan signifikan terhadap niat pembelian pada produk iPhone di Kota Denpasar. Hal ini menunjukkan bahwa persepsi harga produk iPhone yang diterima dengan baik oleh konsumen, mampu mendorong niat konsumen untuk membeli produk iPhone. Brand Image berpengaruh positif dan signifikan terhadap niat pembelian pada 
perusahaan produk iPhone di Kota Denpasar. Hal ini menunjukkan bahwa semakin baik brand image yang terbentuk dalam benak konsumen, maka dapat meningkatkan niat pembelian konsumen pada produk iPhone di Kota Denpasar. Brand Image mampu memediasi pengaruh harga terhadap niat pembelian pada perusahaan produk iPhone di Kota Denpasar. Hal ini menunjukkan bahwa pengaruh harga terhadap niat pembelian akan lebih kuat jika produk tersebut memiliki brand image yang baik dalam benak konsumen.

Berdasarkan kesimpulan dari hasil penelitian, maka saran yang dapat disampaikan yaitu dalam upaya meningkatkan harga yang kompetitif, dapat ditingkatkan dengan cara perusahaan selalu memperhatikan kompetitor smartphone lainnya dalam memberi harga produk dan mencoba untuk menawarkan produk iPhone dengan harga yang lebih terjangkau oleh konsumen, sehingga dapat bersaing dengan produsen smartphone lainnya. Dalam upaya meningkatkan brand image iPhone, dapat ditingkatkan dengan cara perusahaan membuat inovasi terbaru dalam merubah bentuk fisik iPhone dengan design yang lebih eksklusif, agar konsumen tidak merasa bosan dan tertarik untuk melakukan pembelian. Dalam upaya meningkatkan niat pembelian konsumen pada produk iPhone, dapat ditingkatkan dengan cara perusahaan Apple membuat aplikasi atau program yang lebih mudah dan praktis digunakan oleh konsumen, sehingga konsumen tertarik untuk menggunakan produk iPhone.

\section{REFERENSI}

Aaker, D. A. 2002. Managing brand equity. New York, NY: The Free Press.

Ackaradejruangsri, P. 2013. The Effect Of Product Quality Attributes On Thai Consumers' Buying Decision. Ritsumeikan Journal Of Asia Pasific Studies, 33, pp: 14-24.

Alviolita, Purnami. 2015. Pengaruh persepsi harga, kepercayaan, dan orientasi belanja terhadap niat beli secara online (Studi pada Produk Fashion Online di Kota Denpasar), Vol. 4, No. 8. 
Arista, E.Desiarista dan Sri Rahayu Tri Astuti. 2011. Analisis Pengaruh Iklim Kepercayaan Merek, dan Citra Merek Terhadap Minat Beli Konsumen. Aset, Vol 13 (1): Hal. 37-45.

Babu, Md. Samiul Hasan. 2016. A Study On Consumers Psychology On Marketing Tools. Philosophy and Progress. 55(1-2), pp. 125-164.

Bang, H. K., Ellinger, A. E., Hadjimarcou, J., \& Traichal, P. A. (2000). Consumer concern, knowledge, belief, and attitude toward renewable energy: an application of the reasoned action theory. Psychology and Marketing, 17(6).

Chrisandi, Nurina Prisilia. 2014. Hubungan Citra Merek dan Kualitas Pelanggan dengan Loyalitas Pelanggan Produk Apple.Jurnal Ilmiah Mahasiswa Universitas Surabaya, 3(1), h.1-11.

Dahmiri. 2009. Pengaruh Bauran Penjualan Eceran (Retailing Mix) Terhadap Citra Department Store (Studi pada Ramayana Department Store Kota Jambi) Jurnal Manajemen Pemasaran Modern, 1(1), h. 2085-0972.

Dharma Adi, NPS., dan I Putu Gde Sukaatmadja. 2015. Pengaruh Citra Merek, Kesadaran Merek, Dan Kualitas Produk Terhadap Keputusan Membeli Produk Apple. E-Jurnal Manajemen Unud, 4(10), h. 3228-3255.

Falihah, Nurul. 2013. Pengaruh Bauran Strategi Bauran Pemasaran Kepada Pembentukan Brand Image dan Dampak Kepada Keputusan Pembelian Konsumen Hotel X Jakarta. Fakultas Ekonomi Universitas Terbuka. Tesis.

Fianto, A. Y. 2014. The Influence of Brand Image on Purchae Behaviour Through Brand Trust. Business management and Strategy, 5 (2), pp:59-76.

He, Meixian, Zhenquan, band Yuanyuan Yang.2013. an Empirical Study On Impact Of Brand Image Of Travel Agencies On Customer Purchase Intentions. Jurnal Atlantis Press, Paris, France.

Heriyati, Pantri, dan Septi. 2012. Analisis Pengaruh Brand Image dan Kualitas Produk Terhadap Niat Pembelian Konsumen pada Handphone Nexian. Journal of Business Strategy and Execution, 4(2), h. 171-205.

Kotler, Philip \& Kevin Lane Keller. 2009. Manajemen Pemasaran. Edisi Kedua Belas Jilid 1. Jakarta : Erlanga.

Laksana, Fajar. 2008. Manajemen Pemasaran Pendekatan Praktis. Yogyakarta : Erlangga.

Lien Che-Hui Lien, Miin-Jye Wen, Li-Ching Huang, Kuo-Lung Wu. 2015. Online hotel booking: The effects of brand image, price, trust and value on purchase intentions. Management Review xxx (2015) 1e9.

Lin, Long-Yi and Lu, Ching-Yuh. 2010. The Influence of Corporate Image, Relationship Marketing, and Trust on Purchase Intention: The Moderating. 
Musay, Fransisca Paramitasari. 2013. Pengaruh Brand Image Terhadap Keputusan Pembelian (Survey pada Konsumen KFC Kawi Malang). Jurnal Administrasi Bisnis, 3 (2), h. 1-7.

Nugroho, Eko Satria. 2010. Pengaruh Kesadaran Merek, Kualitas Produk dan Harga Terhadap Keputusan Pembelian Laptop Acer. Skripsi. Universitas Brawijaya.

Noerchoidah.2013. Analisis Pengaruh Harga, Kualitas Produk, dan Iklan Terhadap Brand Image dan Keputusan Pembelian Sepeda Motor Merek Kawasaki.Jurnal WIGA Vol. 3 No.1. Maret 2013 ISSN NO 2088-0944.

Purnamasari, S., dan Murwatiningsih. 2015. Brand Image Sebagai Mediasi Pengaruh Promosi, Harga dan Sikap Konsumen Terhadap Keputusan Pembelian Jamu Nyonya Meneer di Semarang Timur. Management analysis Journal, 4 (3), h. 265-272.

Ranto, D. W. 2014. Pengaruh Harga, Desain Produk, Kualitas Produk dan Citra merek Terhadap Keputusan Pembelian Konsumen pada Produk Ukm di Yogyakarta. Akademi Manajemen Administrasi YPK Yogyakarta. 5 (2), h.206-218.

Saeed, R., Rab, N. L., Alhaj, M. J. M., Safraz, H., Zahid, M., dan Moeed, A. 2013. Factor Affecting Consumer purchase Decision in Clothing Industry of Sahiwal, Pakistan. World Applied Sciences journal, 24 (7) , pp.844-849.

Stephanie, Elysia.2013.Pengaruh Kredibilitas Endorser Terhadap Minat Beli melalui sikap atas iklan pada produk shampoo L'oreal di Surabaya. Jurnal ilmiah Mahasiswa Universitas Surabaya, 2 (2), pp: 1-21.

Suciningtyas, W. 2012. Pengaruh Brand Awareness, Brand image dan Media Komunikasi Terhadap Keputusan Pembelian. Management Analysis Journal, 1 (1), h.1-8.

Stanton, W. J (1989) Prinsip-prinsip Pemasaran, Jilid Ketujuh. Jakarta: Erlangga .

Triya, I ketut dan Eka Sulistyawati 2015. Peran Brand Image Dalam Memediasi Pengaruh Celebrity Endorser Terhdap Niat Beli. E-Jurnal Manajemen Unud, Vol. 4, No. 6, 2015: 1722-1734.

Tsai. Wang, Y.H., and C.F. 2014. The Relationship between Citra merekand Niat membeli: Evidence from Award Winning Mutual Funds. The International Journal of Business and Finance Research, 8(2), pp: 27-40.

Wahyuni, N.L.G., dan G. Suparna. 2014. Pengaruh Citra merekdan Product Knowledge Terhadap Niat membeli Produk Tas Tiruan di Kota Denpasar. E- Jurnal Manajemen Universitas Udayana, h: 1022-1034. 
E-Jurnal Manajemen Unud, Vol. 7, No. 12, 2018: 6591 - 6621

Widianto, Eka tomi. 2009. Analisi Pengaruh Faktor-Faktor Marketing Mix Terhadap Keputusan Pembelian Kompor Geni di Sidoarjo. Jurnal Manajemen Fakultas Ekonomi Universitas Pembangunan nasional "Veteran" Jawa Timur.

Zeithaml, Valarie A. (1988). "Consumer Perceptions of Price, Quality and ValueA Means-End Model and Synthesis of Evidence," Journal of Marketing, 52 (July), 2-22. 